J. Clin. Chem. Clin. Biochem.

Vol. 17, 1979, pp. 23-27

\title{
Variation of Trace Element Contents in a Single Human Liver
}

\author{
By W. Koenig, F. W. Richter
}

Fachbereich Physik Philipps-Universität Marburg/Lahn, W. Germany

B. Meinel and J. Ch. Bode

Fachbereich Humanmedizin Philipps-Universität Marburg/Lahn, W. Germany

(Received March 31/August 1, 1978

Summary: Multi element analysis of homogenised samples taken from three different areas of a single human liver was performed for 18 elements by proton induced X-ray emission (PIXE). Small (10-20\%) but statistically significant variations between the element contents of these areas were found for $\mathrm{Cl}, \mathrm{K}, \mathrm{Ca}, \mathrm{Fe}, \mathrm{Cu}, \mathrm{Zn}, \mathrm{Br}, \mathrm{Rb}$ and $\mathrm{Mo}$. These differences are not parallel to each other.

The variation of element content within one area of this single liver did not show any distinct correlation between different elements, nor did it significantly exceed the methodical errors of 3-10\% except for lead.

Thus we conclude from our measurements that the trace element analysis of small liver samples by PIXE is, with the exception of lead, fairly representative for the whole organ.

\section{Streuung des Spurenelementgehaltes innerhalb einer Leber}

Zusammenfassung: Multielementanalysen (18 Elemente) homogenisierter Proben aus drei verschiedenen Regionen einer einzelnen menschlichen Leber wurden mit der Methode der protoneninduzierten Röntgenstrahlungsemission (PIXE) durchgefuhrt.

Geringe (10-20\%), aber statistisch signifikante Schwankungen des Spurenelementgehaltes zwischen den drei Regionen wurden bei den Elementen $\mathrm{Cl}, \mathrm{K}, \mathrm{Ca}, \mathrm{Fe}, \mathrm{Cu}, \mathrm{Zn}, \mathrm{Br}, \mathrm{Rb}$ und $\mathrm{Mo}$ gefunden.

Die gefundenen Abweichungen der Spurenelementgehalte in einer Region dieser Leber zeigten keine Korrelationen und überschritten den methodischen Fehlerbereich von 3-10\% außer bei Blei nicht wesentlich. Es zeigte sich, daß abgesehen von Blei - die von kleinen Leberprobenmengen erhaltenen Spurenelementgehalte durchaus als repräsentativ für das Gesamtorgan angesehen werden dürfen.

\section{Introduction}

The aim of this investigation was to check whether the trace element content of a single sample represents the whole organ, and, in case of inhomogeneously distributed element contents, whether these variations are statistically distributed or correlated to different liver lobes. Such a correlation can be expected since the venous input of the left and the right liver lobe originates at least partially in different areas of the digestive organs (1). Moreover measurements of enzyme activities have shown a variation up to a factor of 1.5 with respect to the different liver lobes in rats $(2,3)$. Schicha et al. (4) observed a nonhomogeneous but parallel distribution of the essential elements $\mathrm{Co}, \mathrm{Fe}, \mathrm{P}, \mathrm{Se}$ and $\mathrm{Zn}$. Van Eijk et al. (5) concluded from their results that there are no differences in the iron content between the left, right or centre part of the human liver.

\footnotetext{
Materials and Methods

Eight closely neighbouring specimens were taken from each of the three liver areas shown in figure 1 and homogenised in a teflon-quartz Potter-Elvehjem-homogenisator after diluting 1:10 with bidistilled water. It has been found that homogenised samples are more suited for trace element analysis of small sample masses by PIXE than tissue sections (6). The liver was taken from a 36 year old patient suffering from glioblastoma complicated by bronchopneumonia who died from circulatory and cardiac failure. Apart from signs compatible with centrolobular blood stasis the liver did not show any pathological change. $10 \mu \mathrm{l}$ (containing about $250 \mu \mathrm{g}$ dry weight) of each homogenised specimen were analysed by proton induced $X$-ray analysis (PIXE) at two proton energies ( 2 and $4 \mathrm{MeV}$ ). In order
} 


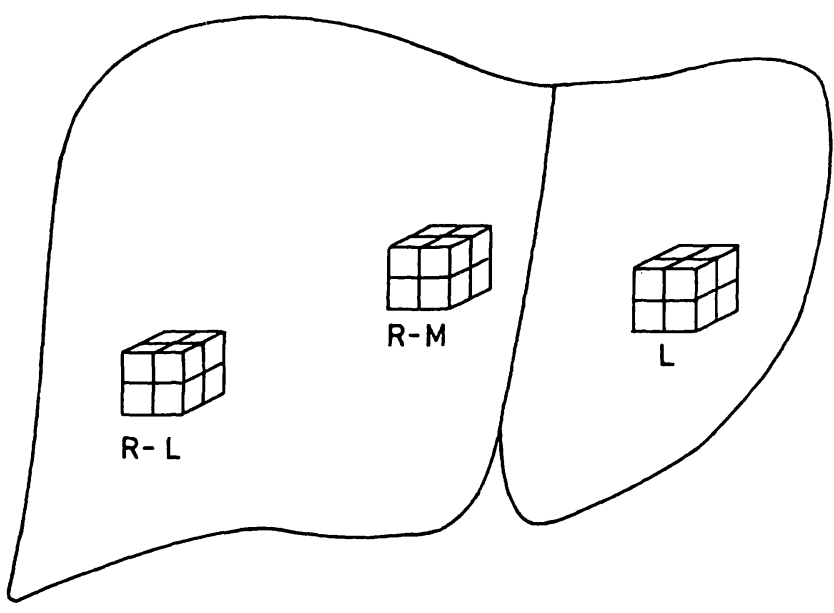

Fig. 1. Sampling points within the liver

R-L: right lobe (lateral)

$\mathrm{R}-\mathrm{M}$ : right lobe (medial)

L: left lobe

From each area eight specimens of about $0.8 \mathrm{~g}$ wet weight were taken.

to check the reproducibility of the analytical method we additionally measured eight samples of $10 \mu l$ taken from one homogenised specimen. The analysis was done in a statistical sequence not correlated to the point of extraction from the liver. The distilled water was analysed both directly, run straight from the distillation and af ter applying the same preparative steps to it as to the liver samples. The measured contaminations were less than $1 \%$ of the trace element contents found within the liver samples. Details of sample preparation are given in $1 . c$.

(6) and of analysis in $1 . c .(6,7)$. The precautions to avoid contaminations published by others (8-11) were taken into account.

Statistical analysis was performed using Student's t-test.

Results

Reproducibility of the measurements

The results of the measurements testing the reproducibility of the method of analysis are shown in table 1. For all analysed elements the relative standard deviation giving the mean error of a single measurement is about $5 \%$ except for $\mathrm{Cr}, \mathrm{Sn}$ and $\mathrm{Cd}$. The contents of $\mathrm{Cr}, \mathrm{Sn}$ and, to a lesser extent, $\mathrm{Cd}$ are close to the detection limit (12), which mainly determines the standard deviation for these elements.

\section{Comparison of trace element contents between different liver areas}

The results of our analysis comparing different liver areas are shown in figure $2 a$ and $b$. The variation of the element from one area to another is almost comparable to the indicated error bars. Therefore, this variation cannot be determined from a single measurement.

But comparing the entire groups of 8 specimens from each area, statistically significant differences are observed (tab. 3). The p-values given in table 3 are

Tab. 1. Standard deviation (in percent) calculated for eight samples taken from one homogenised specimen. The contents of $\mathrm{Cr}$ and $\mathrm{Sn}$ are close to the detection limit. Therefore the large standard deviations are due to the analytical method.

\begin{tabular}{llllllllllllllllll}
\hline Element & $\mathrm{P}$ & $\mathrm{S}$ & $\mathrm{Cl}$ & $\mathrm{K}$ & $\mathrm{Ca}$ & $\mathrm{Cr}$ & $\mathrm{Mn}$ & $\mathrm{Fe}$ & $\mathrm{Cu}$ & $\mathrm{Zn}$ & $\mathrm{Se}$ & $\mathrm{Br}$ & $\mathrm{Rb}$ & $\mathrm{Mo}$ & $\mathrm{Cd}$ & $\mathrm{Sn}$ & $\mathrm{Pb}$ \\
\hline$\sigma(\%)$ & 7.2 & 5.3 & 6.2 & 4.6 & 4.1 & 207 & 10 & 2.8 & 3.6 & 3.1 & 6.6 & 3.9 & 5.0 & 7.2 & 15.5 & 7.5 & 7.1 \\
\hline
\end{tabular}

Tab. 2. Standard deviation (in percent) calculated for eight different samples of each of the three liver areas (for explanation see fig. 1).

\begin{tabular}{lllllllllllllllll}
\hline Element & & $\mathrm{P}$ & $\mathrm{S}$ & $\mathrm{Cl}$ & $\mathrm{K}$ & $\mathrm{Ca}$ & $\mathrm{Mn}$ & $\mathrm{Fe}$ & $\mathrm{Cu}$ & $\mathrm{Zn}$ & $\mathrm{Se}$ & $\mathrm{Br}$ & $\mathrm{Rb}$ & $\mathrm{Mo}$ & $\mathrm{Cd}$ & $\mathrm{Pb}$ \\
\hline$\sigma(\%)$ & $\mathrm{R}-\mathrm{L}$ & 6.1 & 4.2 & 4.1 & 3.4 & 7.5 & 8.8 & 2.5 & 4.6 & 5.1 & 17.4 & 5.5 & 4.0 & 15.9 & 17.8 & 74.4 \\
& $\mathrm{R}-\mathrm{M}$ & 6.9 & 6.8 & 8.8 & 6.3 & 9.5 & 14.9 & 4.6 & 11.3 & 4.0 & 13.8 & 4.5 & 3.3 & 11.8 & 21.3 & 34.6 \\
& $\mathrm{~L}$ & 4.7 & 4.0 & 6.0 & 4.6 & 4.2 & 15.6 & 2.4 & 4.7 & 3.2 & 13.0 & 8.1 & 6.2 & 11.9 & 12.7 & 66.7 \\
\hline
\end{tabular}

Tab. 3. Comparison of trace element contents between different liver areas by applying the t-test for two independent sample groups. p-values are given only in case of $p \leqslant 5 \%$.

$\Delta \overline{\mathrm{x}}$ : relative differences between the mean values of two sample groups.

\begin{tabular}{|c|c|c|c|c|c|c|c|c|c|c|c|}
\hline \multirow{2}{*}{$\begin{array}{l}\text { Sample groups } \\
\text { (8 samples/ } \\
\text { group) }\end{array}$} & & \multicolumn{10}{|c|}{ Element } \\
\hline & & $\mathbf{P}$ & $\mathrm{Cl}$ & $\ddot{\mathbf{K}}$ & $\mathrm{Ca}$ & $\mathrm{Fe}$ & $\mathrm{Cu}$ & $\mathrm{Zn}_{\mathbf{n}}$ & $\mathrm{Br}$ & $\mathbf{R b}$ & Mo \\
\hline & $\begin{array}{l}\Delta \overline{\mathrm{x}}(\%) \\
\mathrm{p}(\%)\end{array}$ & & $\begin{array}{r}-8.4 \\
1.6\end{array}$ & & & $\begin{array}{r}-4.5 \\
1.5\end{array}$ & $\begin{array}{r}-17 \\
1.0\end{array}$ & $\begin{array}{c}-10 \\
0.02\end{array}$ & & $\begin{array}{r}+3.3 \\
3.7\end{array}$ & $\begin{array}{c}-19 \\
0.7\end{array}$ \\
\hline & $\begin{array}{l}\Delta \bar{x}(\%) \\
\mathrm{p}(\%)\end{array}$ & & $\begin{array}{l}-15 \\
0.002\end{array}$ & $\begin{array}{r}+8.5 \\
0.6\end{array}$ & $\begin{array}{r}-10 \\
0.2\end{array}$ & $\begin{array}{l}-12 \\
7 \cdot 10^{-6}\end{array}$ & & $\begin{array}{r}-4.5 \\
3.0\end{array}$ & $\begin{array}{r}-8.1 \\
0.4\end{array}$ & $\begin{array}{r}+9.1 \\
0.2\end{array}$ & \\
\hline $\mathrm{R}-\mathrm{M}$ & $\begin{array}{l}\Delta \bar{x}(\%) \\
\mathrm{p}(\%)\end{array}$ & $\begin{array}{r}+5.6 \\
4.1\end{array}$ & $\begin{array}{r}-6.9 \\
4.3\end{array}$ & & & $\begin{array}{l}-7.4 \\
0.05\end{array}$ & $\begin{array}{r}+17 \\
0.9\end{array}$ & $\begin{array}{r}6.1 \\
0.3\end{array}$ & $\begin{array}{r}-7.8 \\
0.5\end{array}$ & $\begin{array}{r}+5.8 \\
1.6\end{array}$ & $\begin{array}{c}+19 \\
0.3\end{array}$ \\
\hline$\frac{R-L+R-M}{L}$ & $\begin{array}{l}\Delta \bar{x}(\%) \\
\mathrm{p}(\%)\end{array}$ & & $\begin{array}{r}-11 \\
0.06\end{array}$ & $\begin{array}{r}6.0 \\
0.7\end{array}$ & $\begin{array}{r}-8.0 \\
0.4\end{array}$ & $\begin{array}{l}-9.7 \\
2 \cdot 10^{-5}\end{array}$ & & & $\begin{array}{r}-\overline{7} .9 \\
0.3\end{array}$ & $\begin{array}{r}+7.4 \\
0.2\end{array}$ & · \\
\hline
\end{tabular}



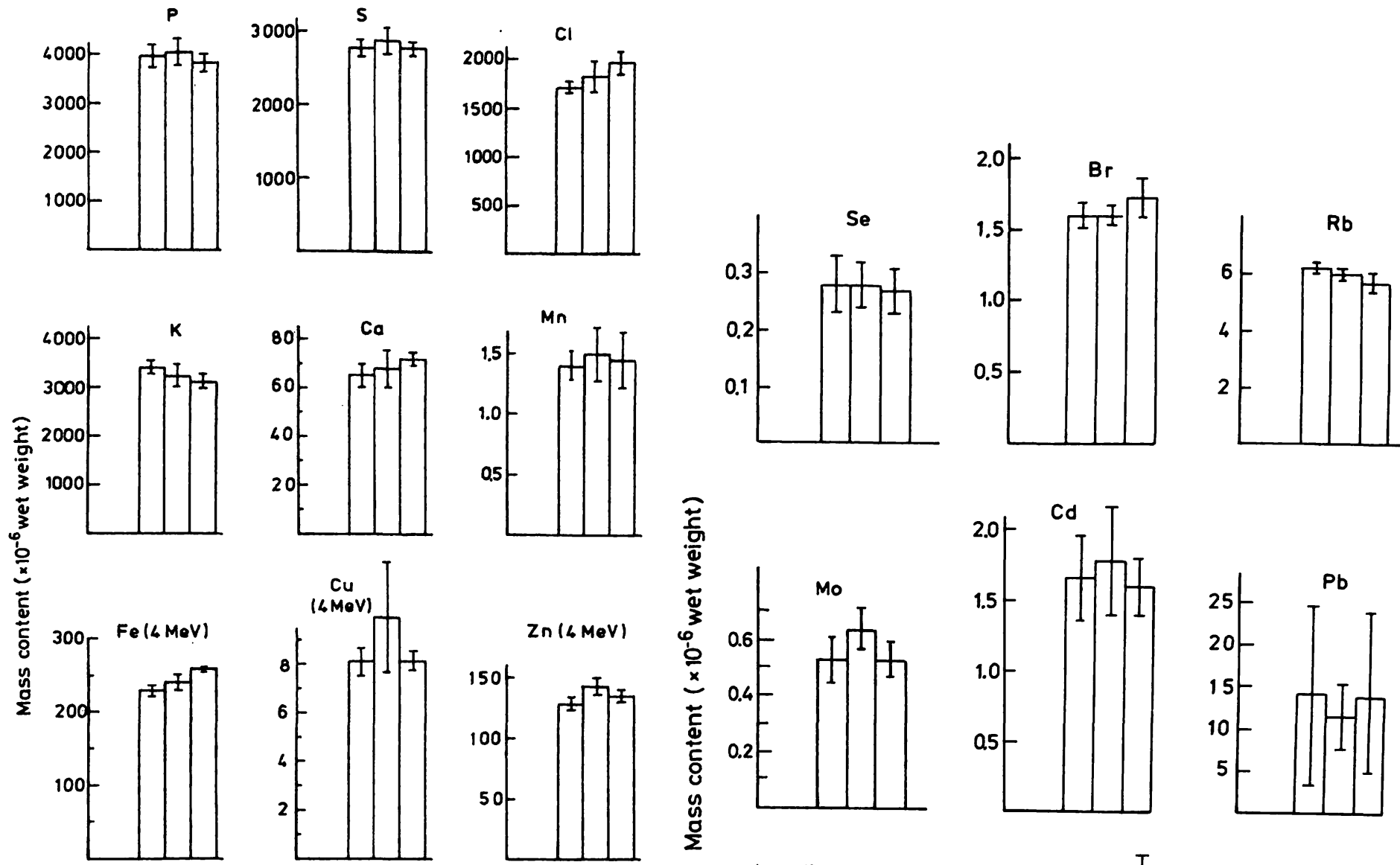

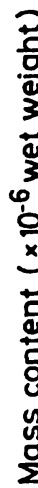

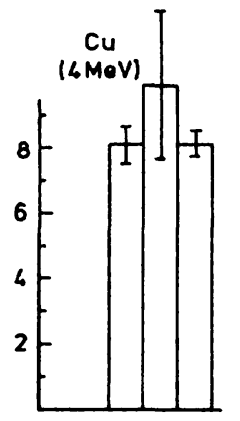

$\mathrm{Zn}(\mathrm{LMeV})$
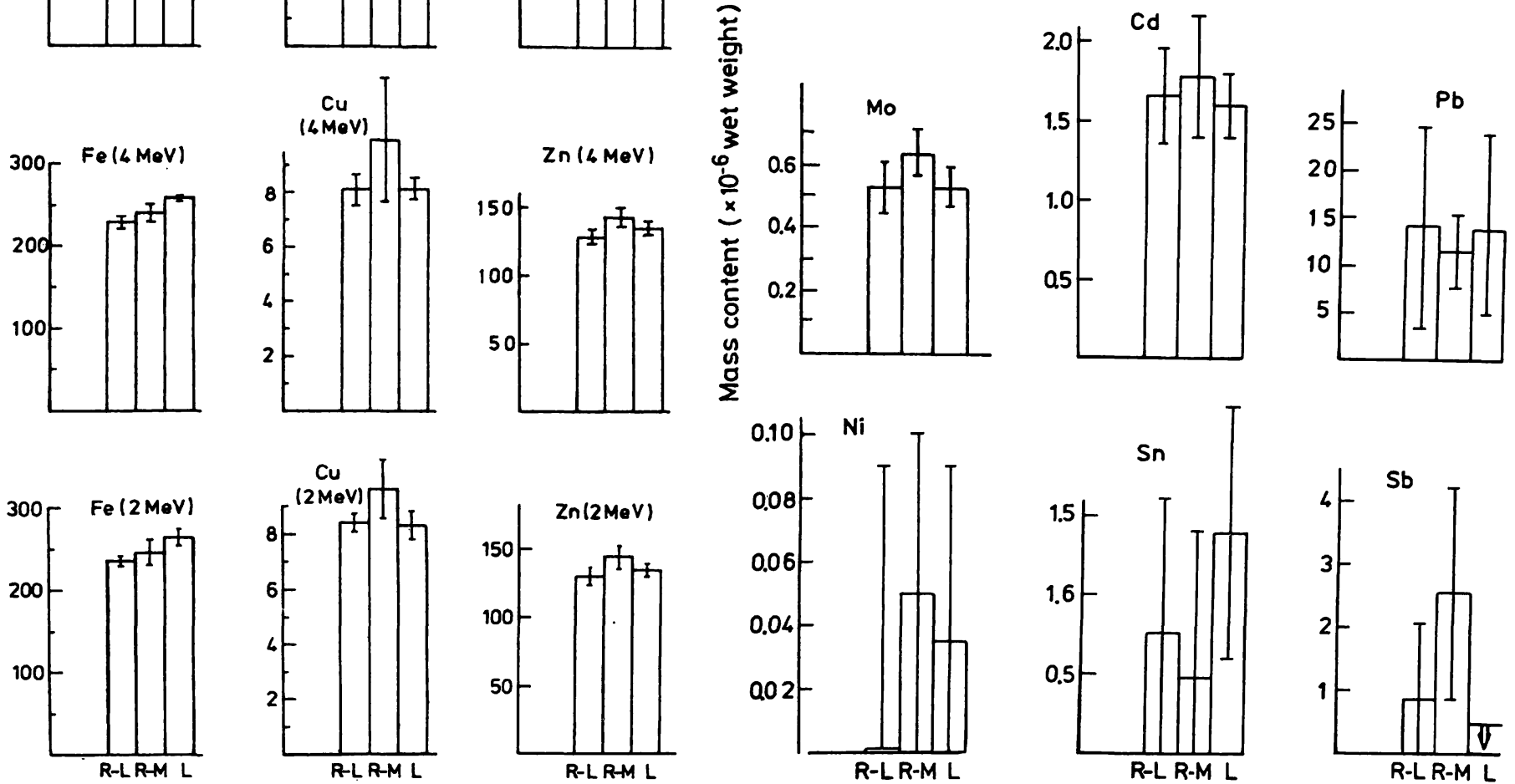

Fig. 2a and b. Mean value and standard deviation of trace element contents in different liver areas. R-L: right lobe (lateral), R-M: right lobe (medial), $\mathrm{L}$ : left lobe. For $\mathrm{Fe}, \mathrm{Cu}, \mathrm{Zn}$ the results of measurements at 2 and $4 \mathrm{MeV}$ proton energy are given separately. The other results are obtained from measurements at only one energy. The mass contents of $\mathrm{Ni}, \mathrm{Sb}, \mathrm{Sn}$ are near the detection limit. Therefore, the large standard deviations are due to the analy tical method.

calculated by integrating the t-distribution between $|t|$ and $\infty$. Further evidence for the significance of the small changes in concentrations is given for all those elements ( $\mathrm{Mn}, \mathrm{Fe}, \mathrm{Cu}, \mathrm{Zn}, \mathrm{Br}, \mathrm{Rb}, \mathrm{Pb})$, which were analysed at both proton energies, showing the same behaviour in the two independent measurements. Since the contents of $\mathrm{Ni}, \mathrm{Sn}$ and $\mathrm{Sb}$ do not exceed the detection limit in all samples, the local differences are subject to large errors. Except for these three elements the measured variations of contents between the analysed liver areas (in general 5-15\%) do not surpass $20 \%(\mathrm{Cu}$, Mo).

The relative standard deviations of the measured trace element contents are given in table 2 for each of the three liver areas. For most elements these values did not exceed significantly those obtained in the test of reproducibility (table 1). Only in the case of lead the relative standard deviation is distinctly higher in all three areas. In addition to lead, an increase in the standard deviation is also observed for Se and Mo by a factor of 2. For these two elements the standard deviation is strongly affected by methodical errors due to data analysis in the presence of a high and distinctly varying lead content. A correlation between the contents of different elements for samples from the same liver area was not observed. Nevertheless, the lowest and highest contents measured within one area were found in the same sample for most of the elements. The maximum deviation from the mean values are given in table 4 for 
Tab. 4. Deviation (in percent) of the lowest and highest values from the mean value measured within one liver area (for explanation see fig. 1).

\begin{tabular}{|c|c|c|c|c|c|c|c|c|c|c|c|c|c|c|c|}
\hline \multirow[t]{2}{*}{ Liver area } & & \multicolumn{2}{|c|}{ Element } & \multirow[b]{2}{*}{$\mathrm{Cl}$} & \multirow[b]{2}{*}{ K } & \multirow[b]{2}{*}{$\mathrm{Ca}$} & \multirow[b]{2}{*}{$\mathrm{Mn}$} & \multirow[b]{2}{*}{$\mathrm{Fe}$} & \multirow[b]{2}{*}{$\mathrm{Cu}$} & \multirow[b]{2}{*}{$\mathrm{Zn}$} & \multirow[b]{2}{*}{$\mathrm{Se}$} & \multirow[b]{2}{*}{$\mathrm{Br}$} & \multirow[b]{2}{*}{$\mathbf{R b}$} & \multirow[b]{2}{*}{ Mo } & \multirow[b]{2}{*}{$\mathrm{Pb}$} \\
\hline & & $\mathbf{P}$ & $S$ & & & & & & & & & & & & \\
\hline R-L & $\begin{array}{l}\operatorname{Max}(\%) \\
\operatorname{Min}(\%)\end{array}$ & $\begin{array}{r}6.3 \\
11.1\end{array}$ & $\begin{array}{l}4.9 \\
7.8 .\end{array}$ & $\begin{array}{l}5.1 \\
6.3\end{array}$ & $\begin{array}{l}4.9 \\
5.7\end{array}$ & $\begin{array}{r}14.4 \\
9.0\end{array}$ & $\begin{array}{l}15.6 \\
13.3\end{array}$ & $\begin{array}{l}4.3 \\
2.1\end{array}$ & $\begin{array}{l}6.2 \\
7.9\end{array}$ & $\begin{array}{l}7.8 \\
8.3\end{array}$ & $\begin{array}{l}28.6 \\
25\end{array}$ & $\begin{array}{r}11.3 \\
5.6\end{array}$ & $\begin{array}{l}4.5 \\
7.6\end{array}$ & $\begin{array}{l}23.0 \\
23.0\end{array}$ & $\begin{array}{l}44 \\
93\end{array}$ \\
\hline R-M & $\begin{array}{l}\operatorname{Max}(\%) \\
\operatorname{Min}(\%)\end{array}$ & $\begin{array}{r}6.9 \\
11.8\end{array}$ & 149.0 & $\begin{array}{l}10.4 \\
17\end{array}$ & $\begin{array}{r}8.7 \\
13.6\end{array}$ & $\begin{array}{l}11.9 \\
15.9\end{array}$ & $\begin{array}{l}29 \\
21\end{array}$ & $\begin{array}{l}4.5 \\
8.5\end{array}$ & $\begin{array}{l}16 \\
13\end{array}$ & $\begin{array}{l}5.2 \\
5.4\end{array}$ & $\begin{array}{l}10.7 \\
25\end{array}$ & $\begin{array}{l}8.1 \\
5\end{array}$ & $\begin{array}{l}4.5 \\
2.8\end{array}$ & $\begin{array}{l}20.6 \\
19.0\end{array}$ & $\begin{array}{l}55 \\
45\end{array}$ \\
\hline L & $\begin{array}{l}\operatorname{Max}(\%) \\
\text { Min (\%) }\end{array}$ & $\begin{array}{l}9.9 \\
5.0\end{array}$ & $\begin{array}{l}7.8 \\
5.5\end{array}$ & $\begin{array}{l}10 \\
8.4\end{array}$ & $\begin{array}{l}5.7 \\
9.9\end{array}$ & $\begin{array}{l}5.0 \\
5.1\end{array}$ & $\begin{array}{l}22.2 \\
22.9\end{array}$ & $\begin{array}{l}3.4 \\
3.4\end{array}$ & $\begin{array}{l}5.2 \\
7.1\end{array}$ & $\begin{array}{l}3.5 \\
5.8\end{array}$ & $\begin{array}{l}11 \\
22\end{array}$ & $\begin{array}{r}6.4 \\
12.7\end{array}$ & $\begin{array}{r}10.4 \\
6.7\end{array}$ & $\begin{array}{l}19.2 \\
19.2\end{array}$ & $\begin{array}{r}129 \\
84\end{array}$ \\
\hline
\end{tabular}

each of the three liver areas. Even these deviations are about $10 \%$ for most of the elements.

\section{Discussion}

From the results of this study it can be concluded that small but significant differences in the element contents exist between different liver areas. These variations are only in some cases parallel to each other especially for chemically similar elements ( $\mathrm{S}-\mathrm{Se}, \mathrm{K}-\mathrm{Rb}, \mathrm{Cl}-\mathrm{Br}$ ). However, for other elements the differences are antiparallel or not correlated and less than observed for other constituents of the hepatocyte, such as reported for enzyme activities $(2,3)$.

Nevertheless, more pronounced differences in the trace element content may exist for other nutritional conditions or diseases of the intestine. Especially in the case of pathological changes in the liver, local scans through the liver might be of interest. Since data of this kind are lacking for most of the essential elements, the sampling area within the liver should always be defined in order to avoid possible misinterpretation.

In addition, it can be concluded that within the same area of the liver no statistical variation of the element content exists, which might be of biological interest, except in the case of lead.

The results reported here do not agree with those of Schicha et al. $(4,13)$. These authors observed larger deviations for $\mathrm{P}, \mathrm{Fe}, \mathrm{Zn}$ statistically distributed within the liver, leading to twofold higher standard deviations. In addition, the range of the element contents given by Schicha et al. is two to four times larger than most of those given in table 4 . The latter point is especially important for the interpretation of a single sample analysis. We could not confirm the parallel variation of the element content found by Schicha, either for the variation within one liver area, or for the significant changes in the element contents between different areas (e. g. see $\mathrm{P}, \mathrm{Fe}, \mathrm{Zn}$ in fig. 2 and 3). One should note at this point that the normalization of trace element masses to the analysed liver mass gives rise to problems, due to the deposition of fat within and connective tissue between the cells. Therefore, a parallel variation of the contents of nearly all trace elements points to an incorrect normalization to the parenchyma cells.

The large variation in the lead content $(\mathrm{max} / \mathrm{min}=$ $30 / 1$ ) points to a problem in analysis of accumulated nonessential but toxic elements. It should be mentioned that the total content of lead within the investigated liver is remarkably high. Obviously, the strong variation in the lead content of this liver is not due to analytical errors, but shows real inhomogeneities, statistically distributed. It therefore has to be considered that even pathological accumulations of lead may not be detected by a determination within a single liver sample up to $1 \mathrm{~g}$ of tissue. This is in accordance with findings of Schicha et al. who observed a similar behaviour for antimony, another nonessential element. A relation between the high lead content and the disease of this patient (malignant tumor of the brain) seems possible especially since Tietz et al. (14) have found an increase of the lead content in the liver of patients with neoplastic diseases.

For the elements $\mathrm{P}, \mathrm{S}, \mathrm{Cl}, \mathrm{K}, \mathrm{Ca}, \mathrm{Mn}, \mathrm{Fe}, \mathrm{Cu}, \mathrm{Zn}, \mathrm{Se}, \mathrm{Br}$, $\mathrm{Rb}, \mathrm{Mo}, \mathrm{Cd}$ the measured variation within the liver even between different liver lobes is small enough, so that a single sample analysis gives reliable results for diagnostic purposes. This becomes especially clear, if one takes into account the individual variations between different livers, which are in the range of a factor of two to four, even for essential elements $(5,15,16)$. The statements above are only true for homogenised samples, which contain enough liver material to average out the microscopic substructure of the liver due to liver lobules and their substructure. As investigations have shown, this seems to be the case even for homogenised biopsy specimen, but it could not be verified for thin sections of biopsy specimen (6). Nevertheless, a more detailed multielement analysis of trace element distributions within the liver for a large number of patients and with exact knowledge of case history (environmental conditions and clinical findings) is necessary to definitely clarify the problem of element variation within the liver.

This investigation was supported by the Deatsche Forschungsgemeinschaft. It contains major parts of the thesis of $B$. Meinel. 


\section{References}

1. Netter, F. A. (1964), Digestive Systems Vol. 3, CIBA collection of medical illustrations, 18. CIBA, New York.

2. Bode, J. Ch. \& Bode, Ch., unpublished observation.

3. Schmidt, E. \& Schmidt, F. W. (1970), Enzymol. Biol. Clin. 11, 67-129.

4. Schioha, H., Feinendegen, L. E., Kasperek, K., Klein, H. J. \& Siller, V. (1970), Beitr. Pathol. 141, 227-232.

5. van Ejik, H. G., Wilting, W. F., Bos, G. \& Goossens, J. P. (1974), Clin. Chim. Acta 50, 275-280.

6. Meinel, B., Bode, J. Ch., Koenig, W. \& Richter, F. W. (1979), this J. 17, 15-21.

7. Hasselmann, I., Koenig, W., Richter, F. W., Steiner, U., Wätjen, U., Bode, J. Ch. \& Ohta, W. (1977), Nucl. Instrum. Methods 142, 163-169.

8. Anand, V. D., White, J. M. \&.Nino, H. V. (1975), Clin. Chem. $21,595-602$.

9. Helman, E. Z., Wallik, D. K. \& Reingold, J. M. (1971), Clin. Chem. 17, 61-62.
10. Tipton, I. H., Cook, M. J., Steiner, R. L., Baye, C. A., Perry, H. M. \& Schroeder, A. A. (1963), Health Phys. 9, 89-101.

11. Webb, J., Niedermeier, W. \& Gripps, J. H. (1973), Appl. Spectrosc. 27, 342.

12. Scheer, J., Voet, L., Wätjen, U., Koenig, W., Rich ter, F. W. \& Steiner, U. (1977), Nucl. Instrum. Methods 142, 333338.

13. Schicha, H., Kasperek, K., Feinendegen, L. E., Stiller, V. \& Klein, H. J. (1972), Beitr. Pathol. 146, 55-62.

14. Tietz, N. W., Hirsch, E. F. \& Negman, B. (1957), J. Am. Med. Assoc. 165, 2187-2192.

15. Koch, H. J., Smith, E. R., Schimp, N. F. \& Connor, J. (1956), Cancer 9, 499-511.

16. Tipton, I. H. \& Cook, M. J. (1963), Health Phys. 9, 103145.
Prof. Dr. F.-W. Richter FB Physik der Universität Renthof 5 D-3550 Marburg

Prof. Dr. med. J. Ch. Bode Medizinische Klinik der Universität Emil Mannkopffstraße 1 D-3550 Marburg 


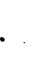

$$
\text { . }
$$

